\title{
Examination of Gross Alpha and Beta Radioactivity Concentration in Tubers and Cereals Obtained from the Oil Producing Areas of Rivers State, Nigeria
}

\author{
Alao, A.A ${ }^{1}$, Ogu M.N.A ${ }^{2}$, Alao, Q.A.T \\ ${ }^{1,2}$ Department of Physics, Federal College of Education (Tech) Omoku, Rivers State, Nigeria \\ ${ }^{3}$ Department of Theatre Arts, Federal College of Education (Tech) Omoku, Rivers State, Nigeria
}

\begin{abstract}
The gross alpha and beta radio activity concentration in tubers and cereals obtained in selected oil fields within the Niger Delta Region of Nigeria have been studied and evaluated. Tubers and cereals samples were harvested, collected and analyzed for gross alpha and beta activity using an IN-20 model gas-flow proportional counter. The results obtained showed that the average gross alpha and beta activity for tuber samples ranged from BDL to $0.294 \pm 0.0391$ and $B D L$ to $0.293 \pm 0.053 \mathrm{~Bq} / \mathrm{g}$ respectively, while the average gross alpha and beta activity for cereal samples ranged from BDL to $0.087 \pm 0.040 \mathrm{~Bq} / \mathrm{g}$ and BDL to $0.414 . \pm 0.040 \mathrm{~Bq} / \mathrm{g}$ respectively. These results revealed an elevation over the activity of the control samples taken from non-oil bearing environment and the World Health Organization standard limit of $0.1 \mathrm{~Bq} / \mathrm{g}$ for gross alpha activity but the average beta activity were all below the WHO standard limit of $1.0 \mathrm{~Bq} / \mathrm{g}$ in all the zones studied. The elevation recorded may be due to oil exploration activities with associated artificial or anthropogenic activities such as gas flare, pollutants, transportation by air media to plant surfaces, frequent oil spillage into and back to the soil or any accidental underground pollutants into the food chain encountered in the surveyed areas. However, the results so obtained may not pose any serious detrimental health side-effects to the public consuming these products.
\end{abstract}

Keywords: Gross Alpha and Beta, Radioactivity, anthropogenic activities, Oil fields

\section{Introduction}

The awareness of the potential degradation of the agricultural products and its environment by the activities of the farmers, residence/commercial activities and others give credence to the need to examine and quantify gross alpha and beta particles content of ingestible materials in human body and the fact that these particles have short ranges and could deposit a lot of energy within a tissue in which they are absorbed. They are inherently charged particles and are capable of causing greater damage due to gross ionization. Therefore, gross alpha and beta data are reliable in health and environmental studies. Radionuclide which enter the human body via foodstuffs, reaches it through a complex mechanism or food chain (Amaral et al., 1998). The season of the year determines to a great extent the magnitude of contamination of different foods or environmental components (IAEA, 1989). As other agricultural products are prone to external contamination during their growing season, roottubers may also become contaminated (Badran et al., 2003). Grains are subjected to contamination during storage and if fall out occurs during the growing season and in the soil. Radionuclide will be transported into grains through the plant growth process (Albrecht et al., 2002). Naturally occurring Radionuclide (NORM) of Thorium and Uranium are significant contribution of ingestion dose and are present in the biotic systems of plants, animals, soil, water and air. Distribution of these radionuclides in different parts of the plants depends on the chemical characteristic and several parameters' of the plant and soil (Shanthi et al., 2009). Shanthi et al., (2009) measured the gross alpha and beta radioactivity in food crops grown in naturally high background radiation areas in South West India and obtained alpha activity to be maximum in tapioca, minimum in Indian Caper $\left(497 \pm 72 \mathrm{Bqkg}^{-1}\right)\left(116 \pm 14 \mathrm{Bqkg}^{-1}\right)$ and beta activity was maximum in paddy grain $\left(10,946 \pm 553 \mathrm{Bqkg}^{-1}\right)$ and minimum in drumstick (190 $\left.\mathrm{BqKg}^{-1}\right)$. Olomo, (1990) study on natural radioactivity in some Nigeria food stuffs varies and concluded that the major factor that may be responsible include, application of fertilizer, soil type and irrigation pattern. Arogunjo et al.,(2004) studied the level of natiral radionuclide in stme Nigerian cereals and tubers using HPGe detector and reported average concentration of ${ }^{40} \mathrm{~K},{ }^{238} \mathrm{U}$ and ${ }^{232} \mathrm{Th}$ as $130+8.12 \mathrm{~B}^{7} \mathrm{~kg}^{-1}, 11.5+3.86$ $\mathrm{B}^{\mathcal{T}} \mathrm{kg}^{-1}$, and $6.78+2.1 \mathrm{BqKg}^{-1}$ respectively.. Radionuclides have always been present in food at various levels depending on factors such as radioactivity contents in soil and the transfer characteristics from the environmental medium to foodstuff, and hence to man Amaral et al., 1998; IAEA 1998, Thiery et al.,(2002).Because of a higher concentration of radioactive substances in the environment and food chain is undesirable, the need to evaluate the gross alpha and beta disposition of some tubers and cereals samples within the Niger Delta Region of Nigeria is very important.

\section{Study Area}

As reported in Avwiri et al, 2013, the study area is within the Niger Delta Region of Nigeria. It is situated approximately between latitudes $5^{0} 13^{1}-28^{1} \mathrm{~N}$ and longitude $6^{0} 35^{1}-42^{1}$ E of the North Western quadrant of Rivers State of Nigeria.. Prominent towns and communities within the study area are Omoku, Elele-Alimini; Mbiama, Engenni community, Ebocha, Mgbede and Big Elele. (Figure 1) 


\section{International Journal of Science and Research (IJSR) \\ ISSN (Online): 2319-7064}

Index Copernicus Value (2015): 78.96 | Impact Factor (2015): 6.391

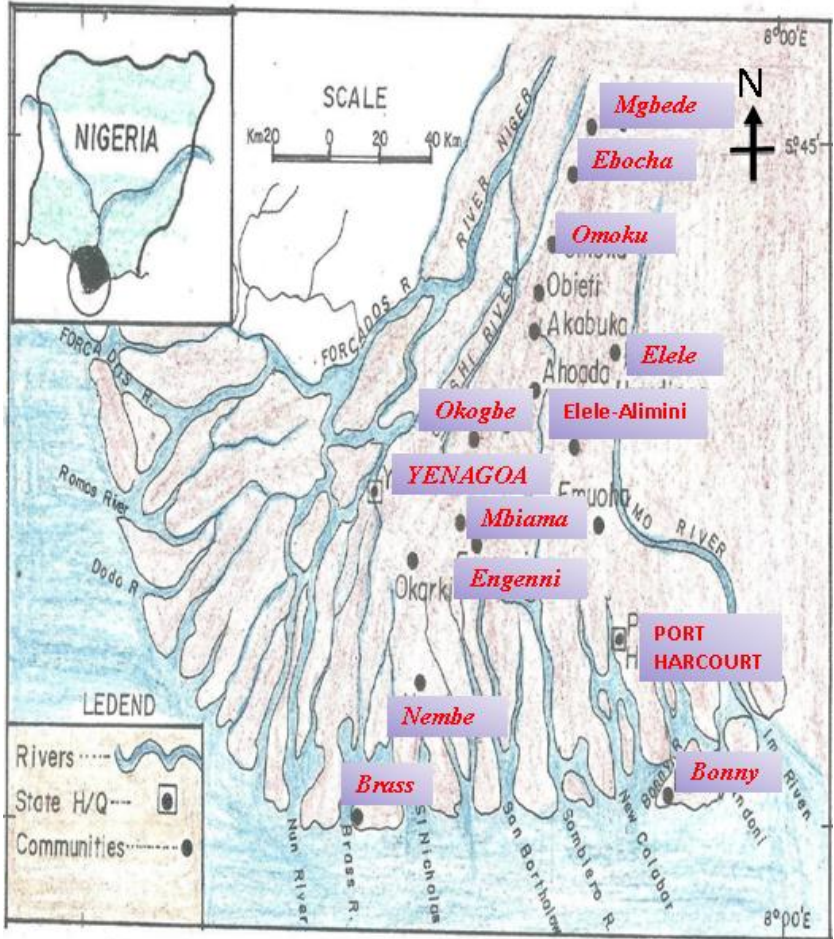

Niger Delta Region of Nigeria Showing Some Communities within (OML 58 \& 61 )

Figure 1: Map of the study area (Source: Avwiri et al, 2013)

\section{Methodology}

\section{Materials and Methods}

Study area was divided into six zones, A,B,C,D,E,F within the region and total of eleven samples (eight tubers and three cereals samples) were collected and spread in trays (properly separated to avoid contamination) and were allowed to dry at room temperature for about ten days. Samples were kept in a slow-air flow temperature of $50^{\circ} \mathrm{C}$ drying cabinet to help accelerate the drying process without loss of radionuclides from the sample. (IAEA, 1989). The dried samples were ground with mortar and pestle and then allowed to pass through a 100- mesh sieve. Prepared samples were pelleted into counting planchet size using the hydraulic compressor machine.

Pelleted samples were kept in desiccators and kept for four weeks to attain a state of secular equilibrium between the respective daughter nuclides of Uranium and thorium.

All the samples were carefully prepared according to International Atomic Energy Agency (IAEA, 1989) specifications for gross alpha and beta analysis after which the samples (contained in their panchets) were stored in desiccators awaiting counting.

Analysis was carried out using IN - 20 model gas-flow proportional counter at the Centre for Energy Research and Training, Ahmadu Bello University, Zaria, Nigeria. The operational modes used for the counting were the $\boldsymbol{\sigma}^{-}$- only mode for alpha counting and the $\mathrm{B}(+\boldsymbol{a})$ mode for beta counting. Each sample was counted three times and the mean used in computing the activity.
The count rate of each sample was automatically processed by the computer using the equation (IN-20 Model Technical Manual, 1991) as shown below:

$$
\mathrm{C}_{(\alpha, \exists)}=\mathrm{R}_{\left({ }_{(\star,},\right)} \times 60 / \mathrm{t}
$$

Where $\mathrm{C}_{\left({ }_{(a)}\right)}=$ the count rate $(\mathrm{cpm})$ of the alpha or beta particle,

$\mathrm{R}_{(\alpha, \exists)}=$ raw count of the alpha or Beta particle, $\mathrm{t}=$ count time (2700 seconds).

Also the activity of each sample was calculated using the equation (IN-20 Model Technical Manual, 1991);

$$
\mathrm{A}_{(a, \exists)}=\left[\mathrm{C}_{(a, \xi)}-\mathrm{B}_{(a, \xi)}\right] \times \frac{\mathrm{U}_{(a, 3)}}{3_{(\sigma, \Xi)} \times S_{(a, 3)} \times V}
$$

Where $\mathrm{A}_{\left({ }^{(}, \exists\right)}=$ alpha or beta activity $(\mathrm{Bq} / \mathrm{L}$ or $\mathrm{Bq} / \mathrm{g})$

$\mathrm{C}_{\left({ }^{\circ}, \exists\right)}=$ count rate of alpha or beta particle

$\mathrm{B}_{\left({ }^{\circ}, \exists\right)}=$ background count of alpha or Beta particle

$\mathrm{U}_{\left({ }^{\star}, \exists\right)}=$ unit coefficient of alpha or beta particle $\left(1.67 \times 10^{-2}=\right.$ conversion factor from $\mathrm{cpm}$ to $\mathrm{cps}$, where $\mathrm{cps}=1 \mathrm{~Bq}$ )

$3_{\left({ }^{a}, \exists\right)}=$ channel efficiency for alpha or beta counting

$\mathrm{S}_{(\alpha, \exists)}=$ sample efficiency for alpha or beta counting

$\mathrm{V}=$ sample volume or mass (litre or $\mathrm{g}$ )

The error associated with sample activity was computed using (IN-20 Model Technical Manual, 1991);

$$
\mathrm{Er}=\left(\frac{\mathrm{R}+{\frac{(100000)^{2}}{\mathrm{~T}_{\mathrm{bgd}}}}_{1 / 2}^{100000} \mathrm{X} \mathrm{B}}{\mathrm{XXXV}}\right. \text {. }
$$

Where $\mathrm{R}=$ sample raw count,

3 = channel efficiency

Tbgd = background count time,

$\mathrm{S}=$ sample efficiency

$\mathrm{U}=$ unit coefficient $\left(1.67 \times 10^{-2}\right)$,

$\mathrm{V}=$ sample volume or mass (Alao, 2016)

\section{Data Presentation}

Table 1: Average Alpha / Beta Activity $(\mathrm{Bq} / \mathrm{g})$ in surveyed tuber samples for all zones

\begin{tabular}{|c|c|c|c|c|}
\hline S/N & Zone & $\begin{array}{c}\text { Sample } \\
\text { Type }\end{array}$ & $\begin{array}{c}\text { Average alpha } \\
\text { Activity (Bq/g) }\end{array}$ & $\begin{array}{c}\text { Average Beta } \\
\text { Activity (Bq/g) }\end{array}$ \\
\hline 1 & A & Tuber & $0.079 \pm 0.042$ & $0.127 \pm 0.057$ \\
\hline 2 & B & Tuber & BDL & $0.090 \pm 0.056$ \\
\hline 3 & C & Tuber & $0.294 \pm 0.039$ & $0.293 \pm 0.053$ \\
\hline 4 & D & Tuber & $0.292 \pm 0.036$ & $0.286 \pm 0.051$ \\
\hline 5 & E & Tuber & BDL & BDL \\
\hline 6 & F & Tuber & BDL & BDL \\
\hline
\end{tabular}

Table 2: Average Alpha / Beta Activity $(\mathrm{Bq} / \mathrm{g})$ in surveyed cereal samples for all zones.

\begin{tabular}{|c|c|c|c|c|}
\hline S/N & Zone & $\begin{array}{c}\text { Sample } \\
\text { Type }\end{array}$ & $\begin{array}{c}\text { Average alpha } \\
\text { Activity }(\mathrm{Bq} / \mathrm{g})\end{array}$ & $\begin{array}{c}\text { Average Beta } \\
\text { Activity }(\mathrm{Bq} / \mathrm{g})\end{array}$ \\
\hline 1 & A & Cereal & $0.034 \pm 0.040$ & $0.414 \pm 0.055$ \\
\hline 2 & B & Cereal & - & - \\
\hline 3 & C & Cereal & $0.087 \pm 0.040$ & BDL \\
\hline 4 & D & Cereal & - & - \\
\hline 5 & E & Cereal & - & - \\
\hline 6 & F & Cereal & BDL & BDL \\
\hline
\end{tabular}


International Journal of Science and Research (IJSR)

ISSN (Online): 2319-7064

Index Copernicus Value (2015): 78.96 | Impact Factor (2015): 6.391

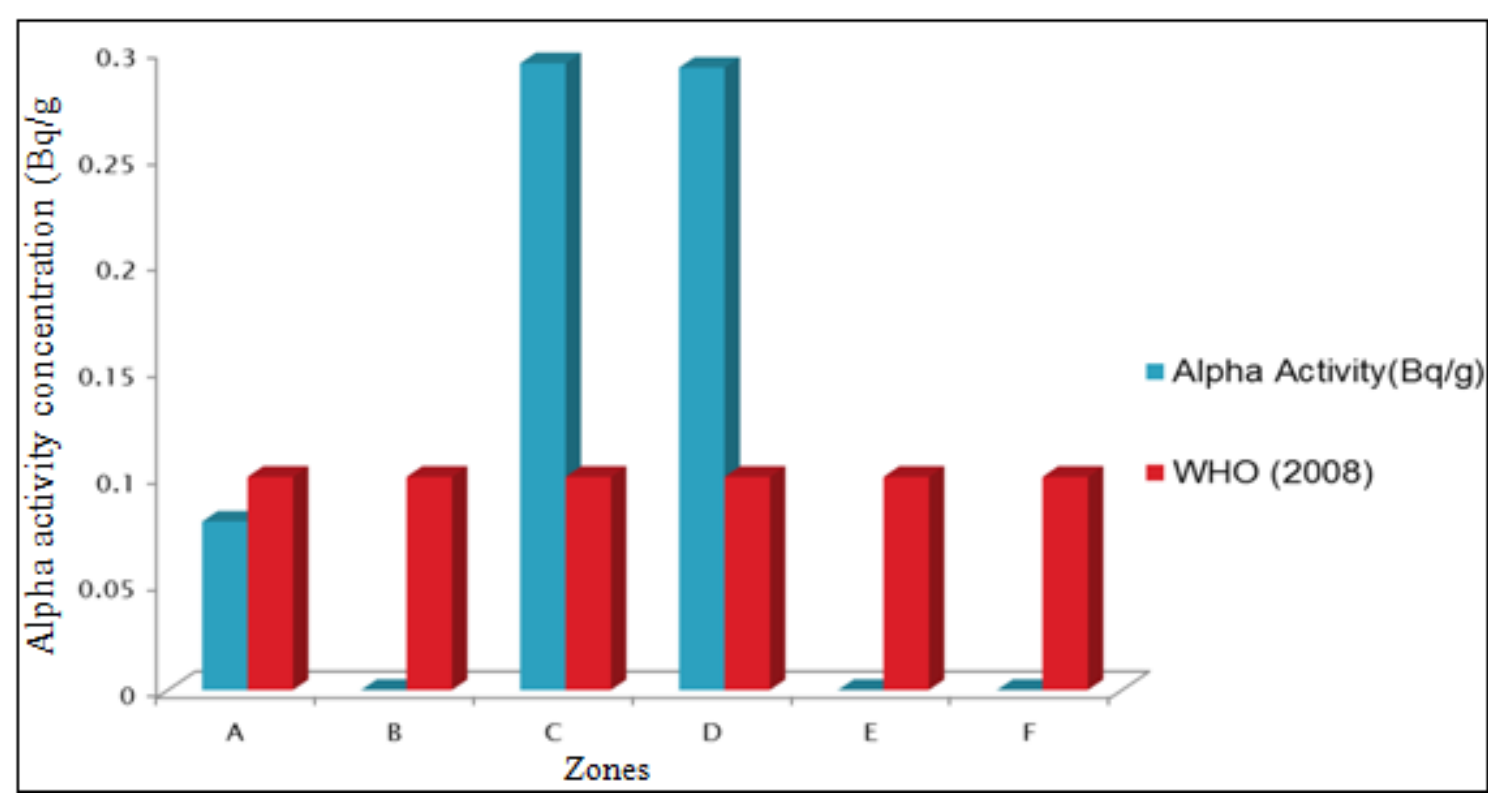

Figure 2: Comparison of alpha activity concentration in tuber samples for all zones with WHO (2008) standard

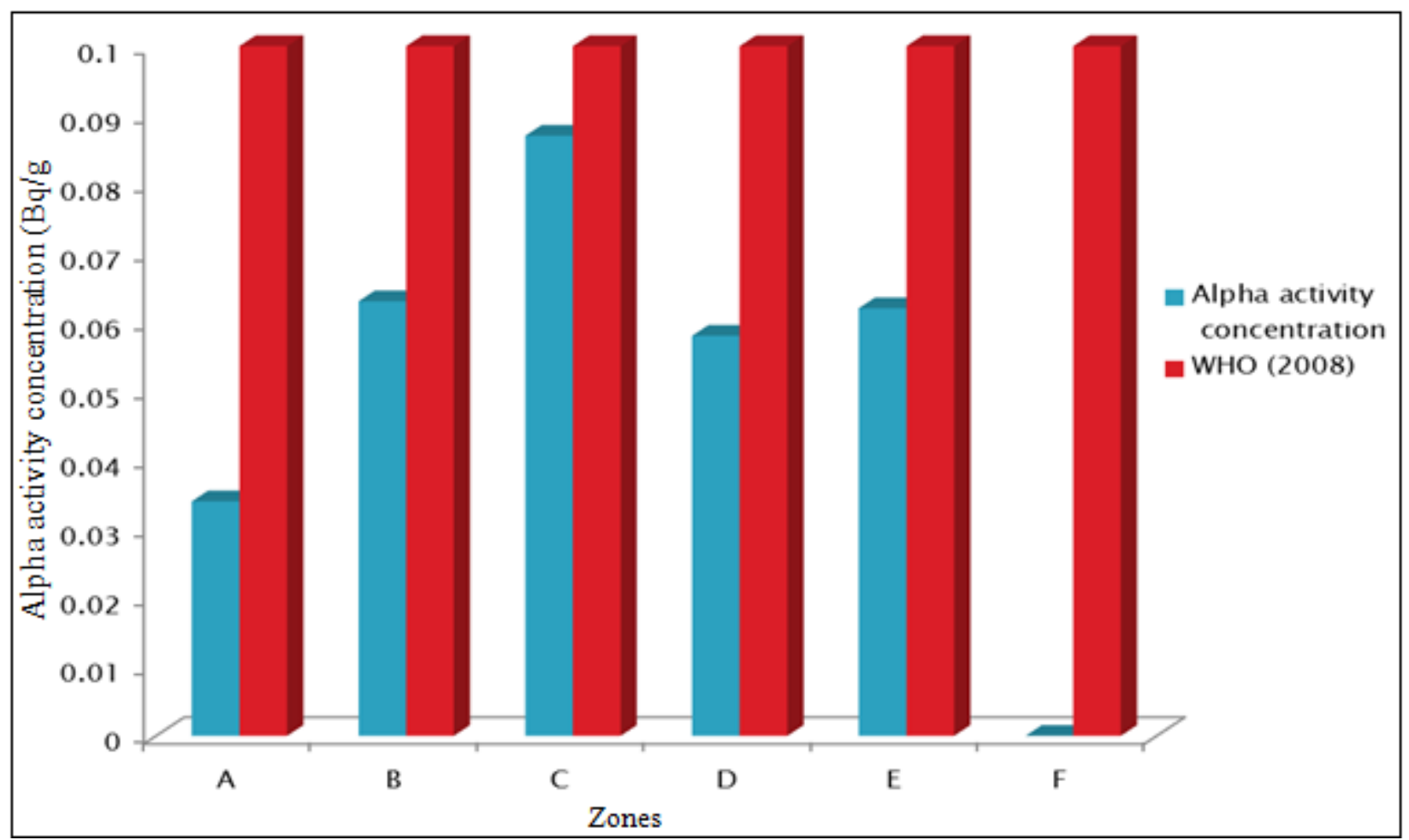

Figure 3: Comparison of alpha activity concentration in cereal samples for all zones with WHO (2008) standard

Volume 6 Issue 7, July 2017

www.ijsr.net

Licensed Under Creative Commons Attribution CC BY 
International Journal of Science and Research (IJSR)

ISSN (Online): 2319-7064

Index Copernicus Value (2015): 78.96 | Impact Factor (2015): 6.391

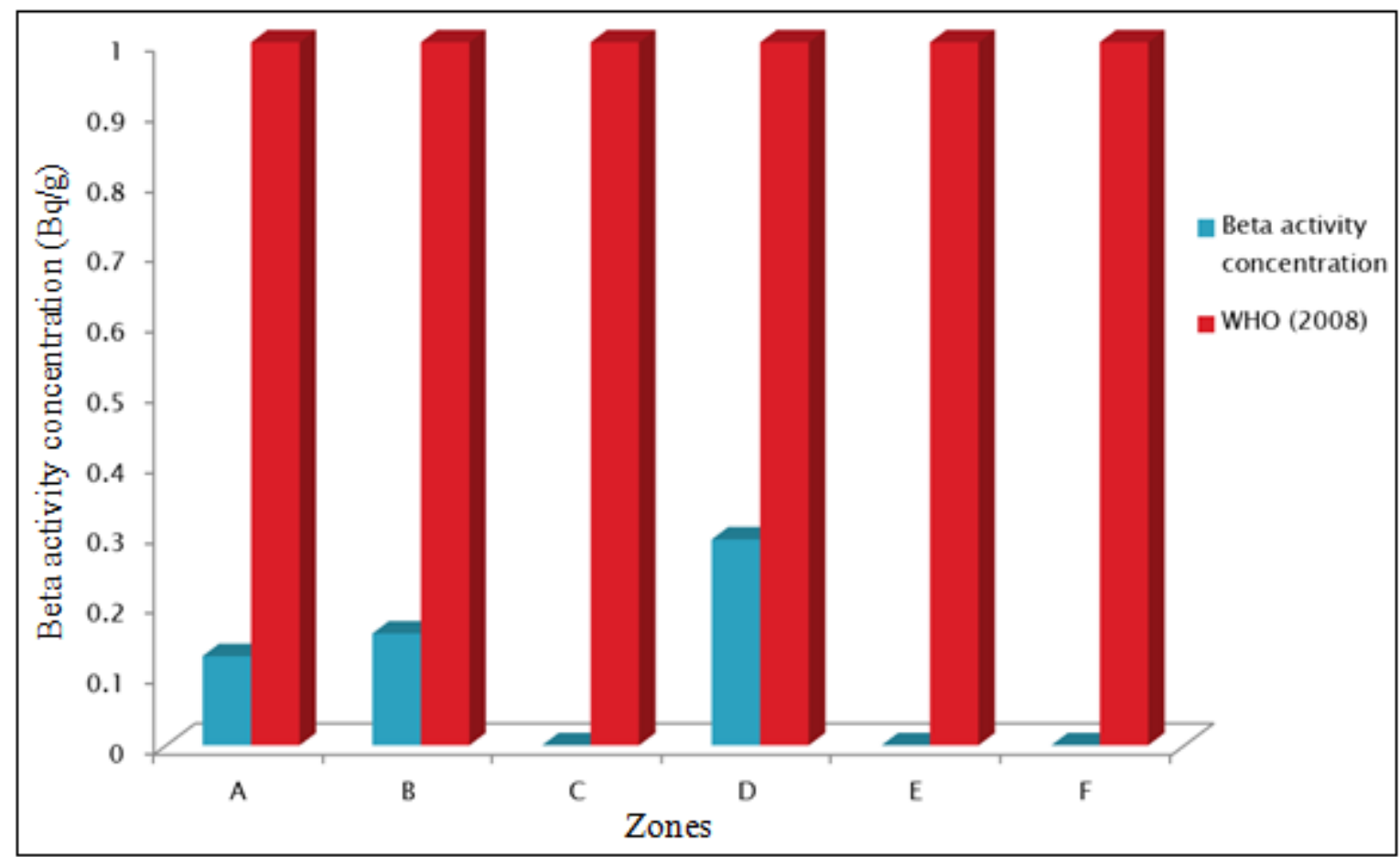

Figure 4: Comparison of beta activity concentration in tuber samples for all zones with WHO (2008) standard

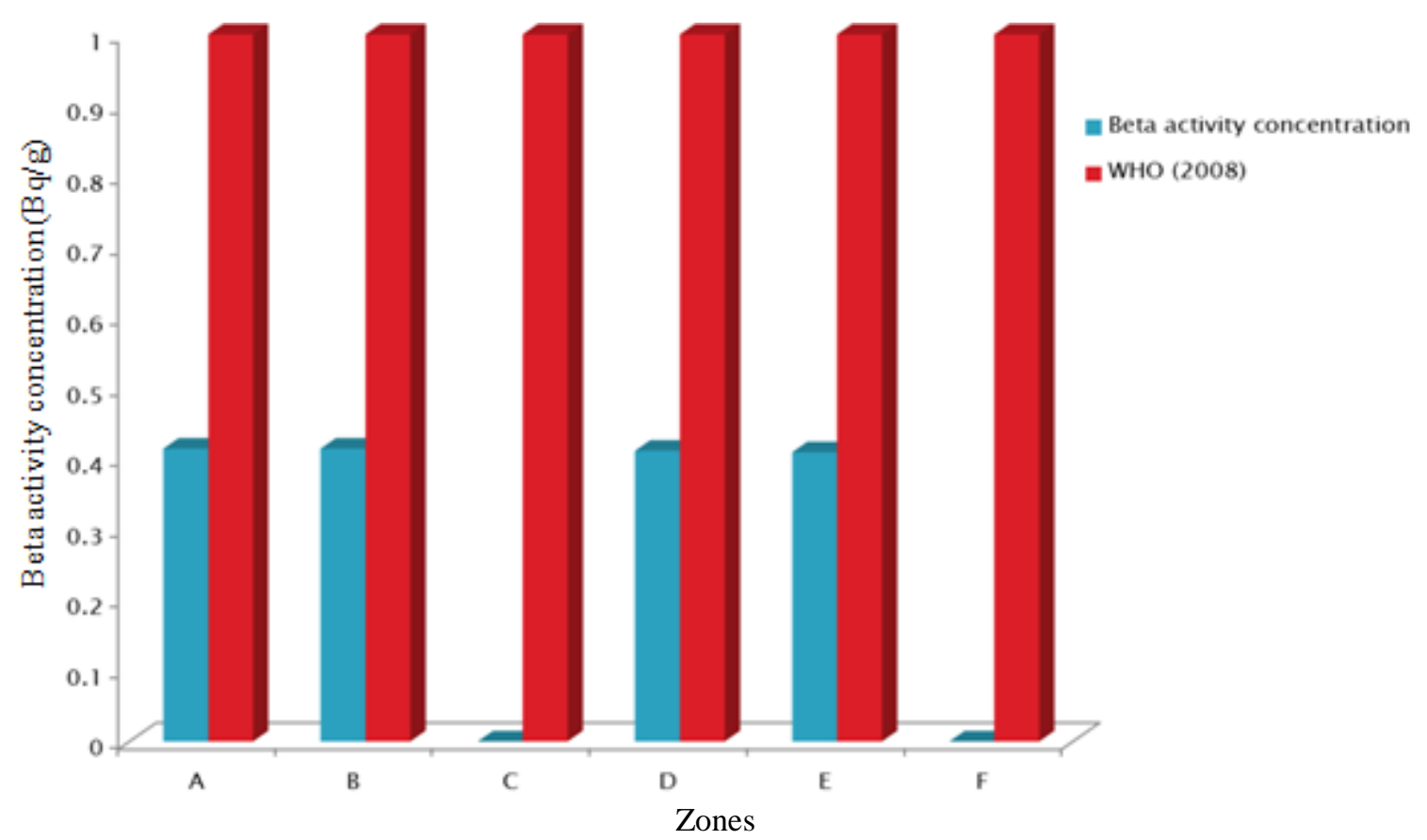

Figure 5: Comparison of Beta activity concentration in cereal samples for all zones with WHO (2008) standard

\section{Results and Discussion}

Discussion of Gross Alpha and Beta Activity Concentration in Surveyed Tuber Samples

Table 1, present the result of the Gross Alpha and Beta Activity Concentration obtained in surveyed tuber samples. Alpha activity concentration ranged from BDL in Yam and Cassava in Zone B, E and $\mathrm{F}$ to $0.294 \pm 0.039 \mathrm{Bqg}^{-1}$ in Cocoyam in Zone $\mathrm{C}$. The average beta activity concentration ranged from $\mathrm{BDL}$ in cocoyam, Zone $\mathrm{F}$ to $0.293 \pm 0.053 \mathrm{Bqg}^{-1}$ in cocoyam in zone C. Gross Beta activity concentration obtained was far below the WHO recommended screening level while average alpha activity concentration was higher than the world standard. The use of artificial fertilizer to improve food crop yield was very prominent in the zone where this slight elevation was observed.

Discussion of Gross Alpha and Beta Activity Concentration in Surveyed Cereal Samples

Table 2 present the result of average Gross Alpha and Beta activity concentration obtained in surveyed cereal samples. Gross Alpha activity ranged from BDL in Maize, Zone F to $0.087 \pm 0.040 \mathrm{Bqg}^{-1}$ in Maize, zone $\mathrm{C}$ while gross beta activity ranged from $\mathrm{BDL}$ in maize, zone $\mathrm{F}$ to $0.414 \pm 0.055 \mathrm{Bqg}^{-1}$ in maize, zone A. All the average results obtained for both Gross alpha and beta activity were below the WHO standard 


\section{International Journal of Science and Research (IJSR) \\ ISSN (Online): 2319-7064 \\ Index Copernicus Value (2015): 78.96 | Impact Factor (2015): 6.391}

screening values for alpha and beta .In comparison, the average values obtained here, are far lower than the average values obtained $\left(10,946 \pm 583 \mathrm{Bqkg}^{-1}\right)$ in paddy grain in HighBackground radiation area in South West India (Shanthi et al., 2009).

\section{Conclusion}

The gross alpha and beta activity concentrations in the surveyed samples from the zones vary from location to location. This may be due to the heterogeneity of radionuclide deposited, since it could be greatly influenced by the type of the soil, water transportation, and man activity in the environment etc. The average alpha activity concentration obtained were all higher than the WHO (2003) recommended safe limit $(0.1 \mathrm{~Bq} / \mathrm{g})$ but that of beta activities were all below recommended safe limit by WHO, 2003. Finally, all the results obtained revealed that the commonly consumed food crops / stuffs surveyed are safe for consumption without posing any immediate radiological threat to the public. However, inhabitants are cautioned against excessive exposure to avoid furtheraccumulative dose of these radiations.

\section{References}

[1] Avwiri; G.O and Agbalagba, E.O (2007).Survey of gross alpha and gross beta radionuclide activity in Okpare-Creek, Delta State, Nigeria. Asian Network for scientific Information. J. Appl. S. 7 (22) 35442 - 3546

[2] Albrecht, A., Schultze U, Liedgens M, Fluhler H, and Frossard E,(2002). Incorporating soil structure and root distribution into plant uptake models for radionuclides: Toward a more physically based transfer model. Journal of Environmental Radioactivity 59: 329-350.

[3] Amaral, E.C.S., Rochedo, E.R.R., Paretzke., H.G,(1998). The radiological impacts of agricultural activities in an area of high natural radioactivity .Radiation protection Dosimetry 45: 289-292.

[4] Badran, H.M., Sharshar, T., and Elnimer T. (2003).Levels of ${ }^{137} \mathrm{Cs}$ and ${ }^{40} \mathrm{~K}$ in edibles Parts of some vegetables consumed in Egypt. Journal of Environmental Radioactivity 67, 181-190.

[5] IAEA, (1989). International Atomic Energy Agency, Measurement of radionuclides in food and the environment. A guidebook, Technical Report Series No. 295, IAEA, Viena

[6] Olomo, J.B., (1990). Natural radionuclide content of some Nigeria foodstuffs. Nuci. Inst. And Methods in Phys. Res. A299:666-669.

[7] Shanthi G., Maniyan C.G, Allan Guana Ray G, Thamp K.J, (2009). Radioactivity in food crops from high background radiation area in South west India.Current Science, Vol.97, No 9.

[8] Thiry, Y., Goor,F, and Riesen, T,(2002). The true distribution and accumulation Ofradiocaesium in stem of Scots Pine (Pinus Sylvestris L).Journal of Environmental Radioactivity Vol.60 (1-2); 235-248.

[9] WHO, (2003).Guidelines for drinking water quality.Third ed., Radiological quality of drinking water, World Health Organization, Geneva, Switzerland.
[10] WHO, (2008).Guidelines for drinking water quality and other screening levels of various categories of foods. 6th ed., World Health Organization, Geneva, Switzerland. 